\title{
Detection of HER-2/neu-positive circulating epithelial cells in prostate cancer patients
}

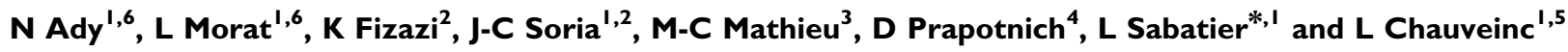 \\ 'CEA, Laboratoire de Radiobiologie et Oncologie, DRR/DSV, 92265 Fontenay-aux-Roses, France; ²Département de Médecine, Institut Gustave Roussy, \\ 94805 Villejuif, France; ${ }^{3}$ Département d'Anatomopathologie, Institut Gustave Roussy, 94805 Villejuif, France; ${ }^{4}$ Service d'Urologie, Institut Mutualiste \\ Montsouris, 75014 Paris, France; ${ }^{5}$ Département de Radiothérapie, Institut Curie, 75005 Paris, France
}

\begin{abstract}
HER-2/neu may play a role in prostate carcinogenesis. The aim of this study was to use the expression of HER-2/neu as a molecular marker for the detection of circulating tumour cells (CTCs) in the blood of patients with prostate cancer (PC). Blood samples were collected from 42 patients with PC and nine healthy volunteers. Immunomagnetic beads were used to harvest epithelial cells from peripheral blood mononuclear cells. Total RNA was extracted and reverse transcribed before analysis by real-time PCR with HER-2/ neu-specific primers. CTCs were HER-2/neu positive in six out of I I (54\%) patients with metastatic disease and in three out of 3 I (9.6\%) patients with localised PC $(P=0.004)$. In blood samples from nine healthy volunteers, we detected no expression of HER-2/ neu. The present method appears to be minimally invasive, highly sensitive and a specific approach for detecting CTCs in PC. Furthermore, it may help better target HER-2/neu in advanced PC.

British Journal of Cancer (2004) 90, 443-448. doi:I0.1038/sj.bjc.660I532 www.bjcancer.com

(C) 2004 Cancer Research UK
\end{abstract}

Keywords: HER-2/neu; circulating tumour cells; prostate cancer; metastatic process

Prostate cancer (PC), the most common cancer in men in western countries, presents a dynamic process in which different clinical and biological phases in both the natural and treated history of the disease may be characterised (Scher and Heller, 2000). The pathways that underlie tumour progression, invasion and resistance to treatment in each clinical state are being increasingly understood, and novel biologic agents that target these pathways are in development or are now available for clinical testing. On the other hand, establishment of new biomarkers is needed to identify high-risk patients as candidates for new (adjuvant) therapies and to find new surrogate endpoints to assess the efficacy of these treatments (De Marzo et al, 2001).

Among serum markers of prostate carcinogenesis, the detection of circulating tumour cells (CTCs) by RT-PCR for prostate-specific antigen (PSA) and prostate-specific membrane antigen (PSMA) mRNA proved to be positive in both peripheral blood and bone marrow (BM). The level of CTCs detected in this setting ranges from 0 to $72 \%$ in patients with clinically organ confined (T1-2) disease and from 25 to $100 \%$ in patients with distant metastases (Israeli et al, 1994; Katz et al, 1994; Ghossein et al, 1995; Seiden et al, 1995; Sokoloff et al, 1996; Corey et al, 1997; Wood and Banerjee, 1997; Mejean et al, 2000; Hara et al, 2002). However, the major question of the specificity of the RT-PCR approach remains unanswered because of illegitimate transcripts in lymphocytes or other blood cells.

\footnotetext{
*Correspondence: Dr L Sabatier; E-mail: sabatier@dsvidf.cea.fr

${ }^{6}$ These authors contributed equally to this work.

Received I 5 April 2003; revised 9 October 2003; accepted 5 November 2003
}

The detection of CTCs using more specific markers such as overexpression of HER-2/neu may be more attractive.

The HER-2/neu oncogene is located on chromosome $17 \mathrm{q} 21$ and it encodes a $185 \mathrm{kDa}$ transmembrane tyrosine kinase receptor of the epidermal growth factor receptor family (Schechter et al, 1985; Yamamoto et al, 1986). Amplification of the HER-2/neu gene and/or overexpression of the protein are found in a variety of human cancers and a number of clinical studies have attempted to correlate its presence with poor patient prognosis (Hynes, 1993; Hynes and Stern, 1994). In breast cancer, HER-2/neu amplification or overexpression, according to standardised criteria, has been described as a marker predicting both response to treatment and poor prognosis with nodal metastases (Slamon et al, 1987; Menard et al, 2000; Yamauchi et al, 2001). Targeting HER-2 using a humanised monoclonal antibody (trastuzumab, Herceptine ${ }^{\mathbb{R}}$ ) in combination with chemotherapy confers a survival benefit for patients with metastatic breast carcinoma that overexpress HER-2 (Slamon et al, 2001), raising the possibility of therapeutic benefits for other types of malignancies that similarly express HER-2. Although the assessment of HER-2/neu overexpression in PC varies widely due to procedural differences, evidence suggests that HER-2/neu may be important in cancer progression (Signoretti et al, 2000). Antitumour activity of anti-HER-2/neu antibody was shown in both androgen-dependent and -independent human xenograft models (Agus et al, 1999). Preliminary clinical trials of trastuzumab have been performed in metastatic PC (Small et al, 2001; Morris et al, 2002). The results of these trials underscored the requirement to better access HER-2/neu expression in order to identify subgroups of patients who may benefit from HER-2/neu targeting. 
The aim of the present study was to use the expression of HER-2/neu as a molecular marker for the detection of cancer cells in the blood of 42 patients with PC and various clinical stages. Indeed, compared to other molecular markers (e.g. PSA), HER-2/ neu has several advantages: it plays a role in prostate tumour progression, and it represents a potential therapeutic target since a commercially available antibody exists and has been successfully tested in the setting of breast cancer. In addition, overexpression of HER-2/neu is highly specific for cancer cells and has never being reported in the blood cells. Therefore, the use of HER-2/neu avoids the problem related to illegitimate transcripts in lymphocytes or other blood cells.

\section{MATERIALS AND METHODS}

\section{Patients}

A total of 42 men, aged 54-81 years, with histologically confirmed PC were included in this study. Blood samples were collected before any treatment in patients with localised PC and during hormone therapy in patients with metastases. All the blood samples were taken at an interval from any biopsy or digital examination. For patients who underwent surgery, blood was collected the day before the surgical procedure. According to clinical status and treatment, patients were divided into two groups: 11 patients with distant metastasis receiving hormone therapy (group 1) and 31 patients with localised PC (group 2). Among patients with localised PC $(n=31), 18$ were treated by radical prostatectomy (patient no. $12-29)$ and 13 by radiation (patient nos. 30-42) (see Tables 1 and 2). For surgically treated patients, localised PC was defined histologically (pT). For patients treated by radiation therapy, $\mathrm{PC}$ was clinically and radiologically defined. All these patients underwent endorectal coil MRI, in order to rule out extracapsular or seminal vesicules invasion. Nine healthy male volunteers, aged 34-60 years, were selected as a negative control group.

\section{Blood samples and immunomagnetic separation of circulating epithelial cells}

Blood samples $(20 \mathrm{ml})$ were collected in heparinised tubes and stored at $4{ }^{\circ} \mathrm{C}$ for a maximum of $2 \mathrm{~h}$ before the experiments. Epithelial cells were separated as described by Soria et al, 1999.

Table I Clinical, pathological and biological status of II patients with metastatic prostate carcinoma ${ }^{\text {a }}$ (group I)

\begin{tabular}{|c|c|c|c|c|c|c|}
\hline $\begin{array}{l}\text { Patient } \\
\text { no. }\end{array}$ & Age & $\begin{array}{l}\text { Score of } \\
\text { gleason }\end{array}$ & M & $\begin{array}{l}\text { Plasmatic } \\
\text { marker: } \\
\text { PSA }^{\text {b,c }}\end{array}$ & Treatment & $\begin{array}{c}\text { Circulating } \\
\text { tumour cells } \\
\text { Status HER-2/neu: } \\
\text { RT-PCR } \\
\text { (LightCycler) }\end{array}$ \\
\hline 1 & 79 & 2 & + & 15 & $\mathrm{HT}$ & - \\
\hline 2 & 67 & 7 & + & 0.8 & $\mathrm{HT}$ & + \\
\hline 3 & 67 & 7 & + & 88 & HT & + \\
\hline 4 & 79 & 7 & + & 0.9 & $\mathrm{HT}$ & - \\
\hline 5 & 74 & 7 & + & 2.38 & None & + \\
\hline 6 & 74 & 4 & + & 0.1 & HT & - \\
\hline 7 & 81 & 4 & + & 2.9 & $\mathrm{HT}$ & + \\
\hline 8 & 72 & 7 & + & 3.1 & $\mathrm{HT}$ & - \\
\hline 9 & 68 & 7 & + & 82.3 & $\mathrm{HT}$ & - \\
\hline 10 & 78 & 5 & + & 508 & $\mathrm{HT}$ & + \\
\hline II & 80 & 4 & + & 492 & $\mathrm{HT}$ & + \\
\hline
\end{tabular}

${ }^{a} \mathrm{HT}=$ hormonotherapy; $\quad \mathrm{CTC}=$ circulating tumour cell; PSA = prostate-specific

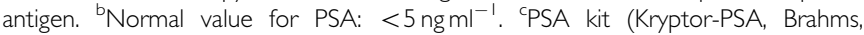
Germany).
Hypaque and resuspended in $1 \mathrm{ml}$ of PBS-2\% FCS. Then, $12.5 \times 10^{6}$ prewashed immunomagnetic beads covalently coated with the BerEP4 monoclonal antibody (Dynal A.S., Oslo, Norway) were added. BerEP4 monoclonal antibody recognises an epitope on the protein moiety of 2 glycopeptides ( 34 and $39 \mathrm{kDa}$ ) expressed at the surface of epithelial cells in normal and malignant tissues (Latza et al, 1990). Following incubation at $4^{\circ} \mathrm{C}$ for $30 \mathrm{~min}$, cells bound to the beads were harvested using a magnetic field. The harvested epithelial cells (HECs) were then washed six times with PBS-2\% FCS. Washing efficiency was controlled by microscopic examination to verify that the samples only contained immunomagnetic bead-coated cells. Cells and beads were then stored at $-80^{\circ} \mathrm{C}$ in two Eppendorf tubes for PCRs.

\section{RNA extraction}

RNA was extracted from cells using the commercially available kit (RNeasy 74104, Qiagen, Hilden, Germany). Samples were stored at $-80^{\circ} \mathrm{C}$ for up to 4 weeks before the assay.

\section{cDNA synthesis}

The detection of HER-2/neu mRNA was performed in a two-step procedure as described by the LightCycler HER-2/neu RNA

Table 2 Clinical, pathological and biological status of 31 patients with localised prostate carcinoma ${ }^{a}$ before radical prostatectomy (patients $12-$ 29) and before treatment by radiation therapy (patients 30-42)

\begin{tabular}{|c|c|c|c|c|c|c|c|}
\hline $\begin{array}{l}\text { Patient } \\
\text { no. }\end{array}$ & Age & $\begin{array}{l}\text { Score of } \\
\text { gleason }\end{array}$ & $\mathbf{T}$ & $\mathbf{N}$ & $M$ & $\begin{array}{c}\text { Plasmatic } \\
\text { marker: } \\
\text { PSA }^{\mathbf{b}}\end{array}$ & $\begin{array}{c}\text { Circulating } \\
\text { tumour cells } \\
\text { Status HER-2/neu: } \\
\text { RT-PCR } \\
\text { (LightCycler) }\end{array}$ \\
\hline 12 & 62 & 6 & $2 b$ & $x$ & 0 & 16.3 & - \\
\hline 13 & 74 & 7 & $3 b$ & 1 & 0 & 17.9 & - \\
\hline 14 & 68 & 5 & $2 a$ & $x$ & 0 & 8 & - \\
\hline 15 & 66 & 5 & $3 a$ & $x$ & 0 & 8.8 & - \\
\hline 16 & 79 & 6 & $3 a$ & $x$ & 0 & 12.2 & - \\
\hline 17 & 64 & 7 & $2 \mathrm{a}$ & $x$ & 0 & 9.1 & - \\
\hline 18 & 67 & 5 & $2 b$ & $x$ & 0 & 5.9 & - \\
\hline 19 & 69 & 6 & $2 b$ & $x$ & 0 & 13.3 & - \\
\hline 20 & 62 & 7 & $3 b$ & $x$ & 0 & 12.5 & - \\
\hline 21 & 60 & 6 & $2 b$ & $x$ & 0 & 7.1 & - \\
\hline 22 & 76 & 6 & $2 b$ & $x$ & 0 & 11 & - \\
\hline 23 & 72 & 6 & $2 a$ & $x$ & 0 & 7 & - \\
\hline 24 & 62 & 6 & $2 b$ & $x$ & 0 & 0.9 & - \\
\hline 25 & 66 & 9 & $3 b$ & $x$ & 0 & 8.5 & - \\
\hline 26 & 57 & 7 & $3 b$ & $x$ & 0 & 8.2 & - \\
\hline 27 & 78 & 9 & $3 b$ & $x$ & 0 & 6.3 & - \\
\hline 28 & 65 & 5 & $2 b$ & $x$ & 0 & 2.6 & - \\
\hline 29 & 55 & 6 & $2 b$ & 0 & 0 & 33 & - \\
\hline 30 & 78 & 2 & IC & 0 & 0 & 6.4 & - \\
\hline 31 & 67 & 7 & IC & 0 & 0 & 6 & - \\
\hline 32 & 74 & 5 & IC & 0 & 0 & 10 & - \\
\hline 33 & 74 & 5 & $2 \mathrm{a}$ & 0 & 0 & 7 & - \\
\hline 34 & 63 & 6 & $2 a$ & 0 & 0 & 35 & + \\
\hline 35 & 58 & 3 & $2 a$ & 0 & 0 & 10 & - \\
\hline 36 & 75 & 7 & $2 a$ & 0 & 0 & 9 & - \\
\hline 37 & 74 & 7 & IC & 0 & 0 & 13 & + \\
\hline 38 & 54 & 6 & Ic & 0 & 0 & 10.6 & - \\
\hline 39 & 58 & 6 & IC & 0 & 0 & 5.9 & + \\
\hline 40 & 57 & 8 & $2 a$ & 0 & 0 & 20 & - \\
\hline 41 & 61 & 8 & $2 a$ & 0 & 0 & 8.9 & - \\
\hline 42 & 66 & 5 & IC & 0 & 0 & 5 & - \\
\hline
\end{tabular}

${ }^{a} \mathrm{HT}=$ hormonotherapy; $\mathrm{ND}=$ not determined; PSA = prostate-specific antigen ${ }^{b}$ Normal value for PSA: $<5 \mathrm{ngml}^{-1}$. T $=\mathrm{pT}$ for patients $12-29, \mathrm{~T}=$ clinical and radiological results for patients $30-42 ; \mathrm{N}=\mathrm{pN}$ for patients $12-29, \mathrm{~N}=$ clinical and radiological results for patients $30-42 ; \mathrm{M}=$ radiological results. 
Quantification Kit (Roche). Briefly, in the first step, cDNA was prepared from RNA by reverse transcription in a final volume of $20 \mu \mathrm{l}$ in a thermal cycler (PTC-200, MJ Research). The samples were incubated at $25^{\circ} \mathrm{C}$ for $10 \mathrm{~min}$, and then $42^{\circ} \mathrm{C}$ for $60 \mathrm{~min}$ and $94^{\circ} \mathrm{C}$ for $5 \mathrm{~min}$. cDNA were stored at $-20^{\circ} \mathrm{C}$.

\section{PCR conditions}

In the second step, a $395 \mathrm{bp}$ fragment of HER-2/neu mRNA was amplified from cDNA by PCR using specific primers (LightCyclerHER2/neu RNA Quantification Kit, Roche, Mannheim, Germany). The amplicon was detected by fluorescence using a specific pair of Hybridisation Probes consisting of two different oligonucleotides labelled at the $5^{\prime}$-end with LightCycler-Red 640 and at the $3^{\prime}$-end with LightCycler-Fluorescein. Only after hybridisation to the template DNA do the two probes come in close proximity, resulting in fluorescence resonance energy transfer (FRET) between the two fluorophores measured by the LightCycler instrument. The kit included a calibrator containing a stabilised fraction of total RNA purified from an immortalised cell line constitutively expressing HER-2/neu. The efficiency of PCR was assessed with serial dilutions of this calibrator in each run. For quantification, crossing point $(\mathrm{Cp})$ was used, the cycle at which PCR amplification begins its exponential phase and is considered the point most reliably proportional to initial concentration. The amount of mRNA encoding for HER-2/neu is expressed as a relative ratio to a reference gene $(\mathrm{G} 6 \mathrm{PDH})$ in a sample relative to the Her-2/neu: G6PDH ratio in a calibrator.

Of the total reverse transcription volume of $20 \mu \mathrm{l}, 4 \mu \mathrm{l}$ was used for each PCR. The polymerase amplification was performed in a total volume of $10 \mu$ l. Each experiment was performed in duplicate. The thermal cycling conditions were: denaturation for $20 \mathrm{~min}$ at $95^{\circ} \mathrm{C}$ followed by amplification $10 \mathrm{~s}$ at $95^{\circ} \mathrm{C}$, then $15 \mathrm{~s}$ at $65^{\circ} \mathrm{C}$ and $15 \mathrm{~s}$ at $72^{\circ} \mathrm{C}$ for 50 cycles, terminated by a cooling step $30 \mathrm{~s}$ at $40^{\circ} \mathrm{C}$.

\section{RESULTS}

\section{Determination of assay sensitivity}

We analysed the sensitivity of the present method by serial dilutions of SK-BR-3 cell line, which is used as a reference for overexpression of HER-2/neu (Pergram et al, 1997). The lower limit of detection was that of $\leqslant 1$ cell ml$^{-1}$ of blood (Figure 1).

\section{Detection of HER-2/neu transcripts in CTCs in the blood of healthy volunteers}

In blood samples from nine healthy volunteers, we detected no expression of HER-2/neu.

\section{Detection of HER-2/neu transcripts in CTCs in the blood of patients with PC}

Group 1 (metastatic PC) Group 1 included 11 patients with metastatic PC. The median age of these patients was 74 years (range, 67-81). Of these 11 patients, six (54\%) were positive for the detection of HER-2/neu.

Group 2 (localised PC) Group 2 included 31 patients with T1c-T3b PC from whom blood was collected before treatment by radical prostatectomy or radiation therapy. The median age was 66.5 years (range, $54-79$ ). Of these 31 patients, three $(9.6 \%)$ were positive for the detection of HER-2/neu.

Tables 1 and 2 summarise the biological, clinical and pathological status of patients at sampling time.

The specific association of HER-2/neu transcripts with the presence of epithelial cells in patients with PC was demonstrated by the absence of contaminating lymphocytes in HEC samples. The washing efficiency and lack of lymphocytic contamination were controlled for each sample by microscopic examination to verify that samples only contained immunomagnetic beadcoated cells (Figure 2 shows an example of this cytologic analysis from patient \#34).

We studied the relationship of HER-2/neu positivity in CTCs of patients with different clinical status. The rate of HER-2/neu detection in CTCs of patients with metastatic PC was significantly higher than that of patients with localised disease (Fisher's exact test, $P=0.004$ ) (see Table 3 ).

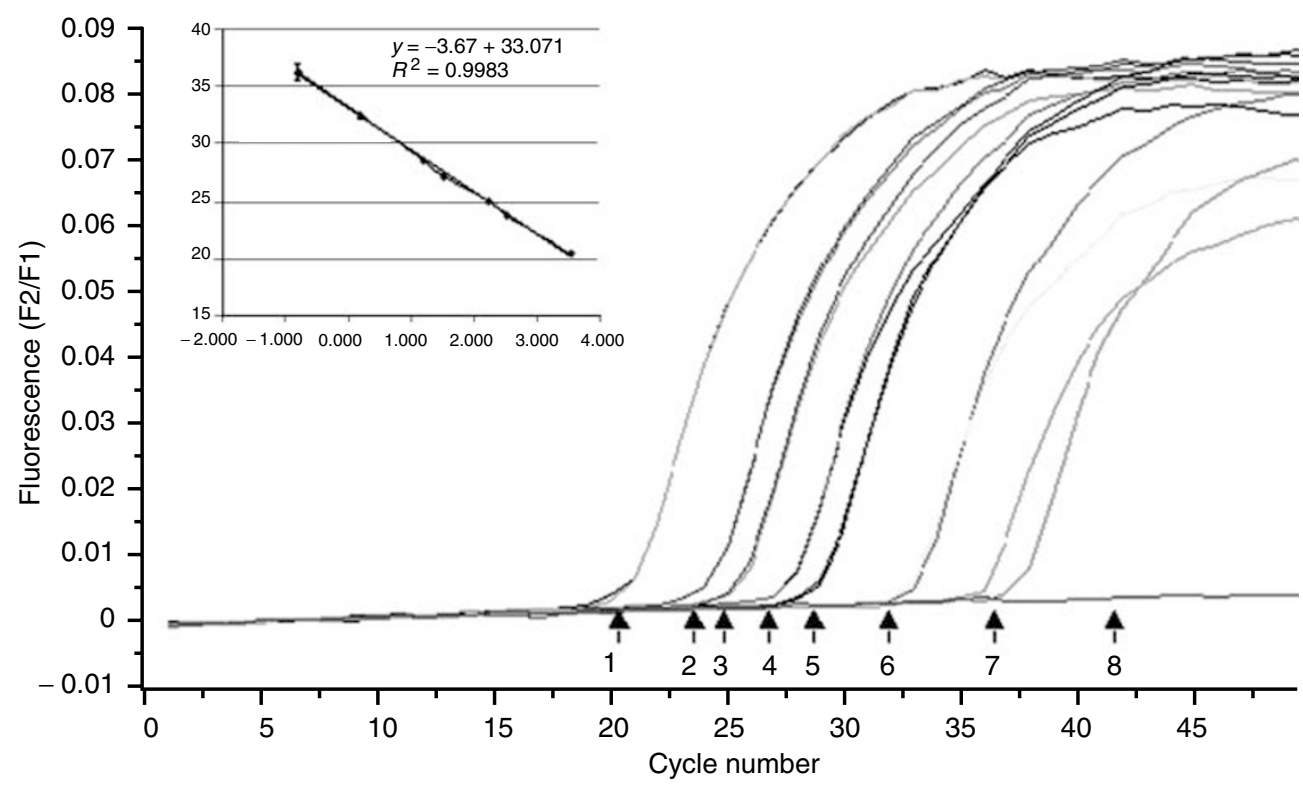

Figure I Expression of HER-2/neu RNA by real-time PCR (LightCycler). Amplification curve shows serial dilutions of an initial amount of SK-BR-3 RNA: I (3333 cells), 2 (333 cells), 3 ( 166 cells), 4 (33 cells), 5 ( 16 cells), 6 ( 1.6 cells) and 7 ( 0.6 cells). Inset, standard curve plot of the log of SK-BR-3 RNA cells numbers vs $C p$. The standard curve shows seven orders of linear dynamic range $\left(y=-3.67 x+33.07 I ; R^{2}=0.9983\right)$. 


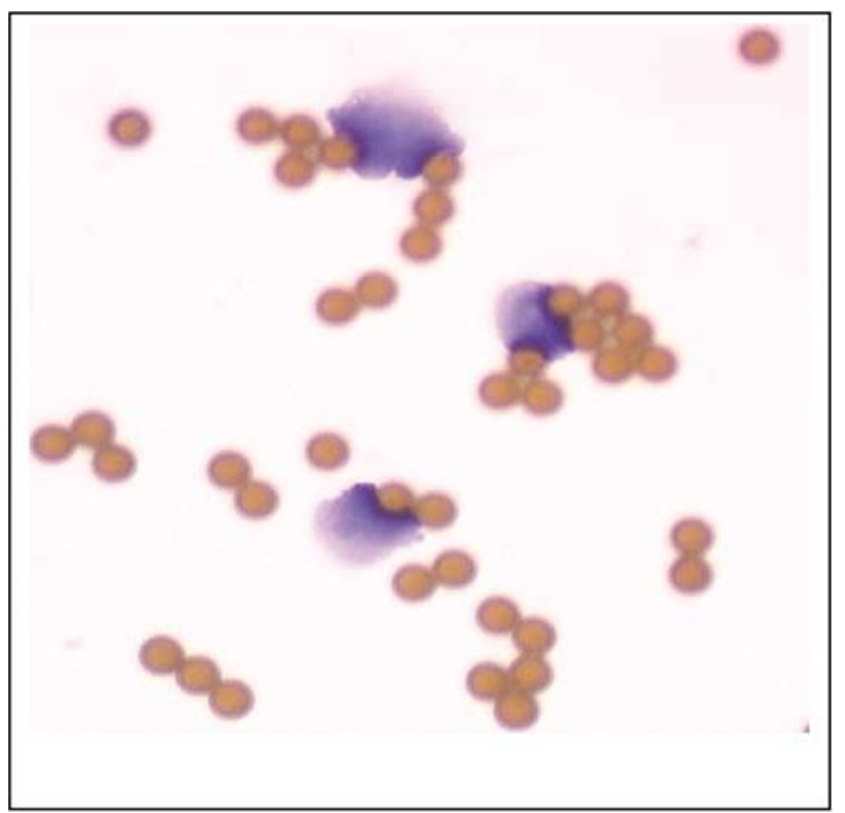

Figure 2 Carcinoma cells isolated with BerEP4-coated immunomagnetic beads from patient no. 34, coloration by May-Grünwald-Giemsa (CTCs isolated from a patient with localised prostate carcinoma before treatment by brachytherapy, this was an HER-2/neu-positive patient).

Table 3 HER-2/neu expression in CTCs of prostate cancer patients according to clinical status

\begin{tabular}{lcc}
\hline Patient characteristics & $\begin{array}{c}\text { Number of } \\
\text { patients }\end{array}$ & $\begin{array}{l}\text { Positive } \\
\text { cases \% }\end{array}$ \\
\hline Metastatic PC (group I) & 11 & $6(54 \%)$ \\
Localised PC (group 2) & 31 & $3(9.6 \%)$ \\
\hline$* P=0.004$ by Fisher exact test. CTC & circulating tumour cell: PC $=$ prostate cancer
\end{tabular}

\section{DISCUSSION}

RT-PCR of several prostate-related genes (PSA, PSMA) as well as immunohistochemical assays (PSA, CK 18) have been used to detect circulating PC cells, but none of these techniques is currently applied in the clinical setting. To our knowledge, HER$2 /$ neu has not been used for detecting CTCs from PC. In the present study, we have combined immunomagnetic separation of circulating epithelial cells with RT-PCR detection of the HER-2/ neu transcripts, in order to increase the specificity and better characterise the molecular profile of CTCs. Nevertheless, the complexity of the present technique should be kept in mind, if its implementation in clinical practice is envisioned. Furthermore, it is important to highlight that the present procedure cannot ensure that the circulating cancer cells detected are PC cells. Indeed, such CTC could be from another epithelial cancer expressing Her2/neu (e.g. bladder cancer). Nevertheless, this is not a frequent clinical situation, especially in patients with radiological and clinical follow-ups.

Evidence suggests that co-operative signalling via c-erbB receptors (such as, HER-1, HER-2/neu, HER-3 and HER-4) can regulate many key processes such as angiogenesis and invasion in most cancers (Eccles, 2001; O-charoenrat et al, 2002). In vitro, HER-2/neu induced metastatic capacities, when it was transfected into a PC cell line (Zhau et al, 1999). When evaluated by immunohistochemistry (IHC), HER-2/neu expression varies largely from one study to another because of methodologic differences and heterogeneity of PC ( $\mathrm{Gu}$ et al, 1996; Lara et al,
$\mathrm{PC}$

\begin{tabular}{|c|c|c|c|c|}
\hline \multirow[b]{2}{*}{ Author } & \multirow[b]{2}{*}{ Marker } & \multirow[b]{2}{*}{ Sample } & \multicolumn{2}{|c|}{$\begin{array}{l}\text { RT-PCR or PCR } \\
\text { positive/total(\%) }\end{array}$} \\
\hline & & & $\begin{array}{l}\text { Localised } \\
\text { PC }\end{array}$ & $\begin{array}{l}\text { Metastatic } \\
\text { PC }\end{array}$ \\
\hline \multirow{3}{*}{$\begin{array}{l}\text { Katz et al } \\
\text { Israeli et al }\end{array}$} & PSA mRNA & Blood & $25 / 65$ (38\%) & |4/I 8 (78\%) \\
\hline & PSA mRNA & Blood & $0 / 18(0 \%)$ & $6 / 24(25 \%)$ \\
\hline & PSMA mRNA & Blood & $13 / 18(72 \%)$ & $16 / 24(67 \%)$ \\
\hline \multirow{4}{*}{$\begin{array}{l}\text { Seiden et al } \\
\text { Ghossein et al } \\
\text { Sokoloff et al }\end{array}$} & PSA mRNA & Blood & $3 / 41$ (7\%) & $11 / 35(31 \%)$ \\
\hline & PSA mRNA & Blood & $4 / 25(16 \%)$ & $26 / 76(34 \%)$ \\
\hline & PSA mRNA & Blood & $43 / 69(62 \%)$ & $29 / 33(88 \%)$ \\
\hline & PSMA mRNA & Blood & $12 / 69(17 \%)$ & $13 / 33(39 \%)$ \\
\hline \multirow[t]{2}{*}{ Corey et al } & PSA mRNA & Blood & $12 / 63(19 \%)$ & $6 / 13(46 \%)$ \\
\hline & & $\mathrm{BM}$ & $45 / 63(71 \%)$ & $10 / 13(77 \%)$ \\
\hline \multirow{6}{*}{$\begin{array}{l}\text { Wood and Banerjee } \\
\text { Mejean et al } \\
\text { Laribi et al } \\
\text { Hara et al }\end{array}$} & PSA mRNA & BM & $39 / 86(45 \%)$ & NA \\
\hline & PSA mRNA & Blood & NA & $9 / 9(100 \%)$ \\
\hline & Prostasin mRNA & Blood & $18 / 69(26 \%)$ & $17 / 27(63 \%)$ \\
\hline & PSA mRNA & Blood & $|/ 4|(2.4 \%)$ & $7 / 14$ (50\%) \\
\hline & PSMA mRNA & Blood & $2 / 41(4.9 \%)$ & $9 / 14(64 \%)$ \\
\hline & PSCA mRNA & Blood & $0 / 41(0 \%)$ & $7 / 14(50 \%)$ \\
\hline Present series & HER-2/neu mRNA & Blood & $3 / 31(9.6 \%)$ & $6 / 11(54 \%)$ \\
\hline
\end{tabular}

$\mathrm{CTC}=$ circulating tumour cell; $\mathrm{BM}=$ bone marrow; $\mathrm{PC}=$ prostate cancer; $\mathrm{PSA}=$ Prostate-specific antigen; PSMA = prostate-specific membrane antigen; PSCA = prostate stem cell antigen.

2002). The published incidence of HER-2/neu overexpression is typically in the range of $25-40 \%$ and $60-80 \%$, respectively, in localised PC (Sadasivan et al, 1993; Ross et al, 1997; Fossa et al, 2002) and in metastatic PC (Osman et al, 2001; Morris et al, 2002). An elevation of serum HER-2/neu was also observed for detection of the extracellular domain of the protein by immunoradiometric assay in patients with advanced cancer stages (Arai et al, 1997). However, alterations in the HER-2/neu expression as a tumour progression marker from localised to metastatic PC have yet to be fully established. Nevertheless, in vitro and clinical studies have linked HER-2/neu expression to the development of late androgenindependent disease (Craft et al, 1999; Signoretti et al, 2000). These data suggest that HER-2 overexpression would be higher if a tumour sample can be obtained from patients with androgenindependent disease. This is a difficult challenge, because very few of these patients have diseases that can be biopsied readily, because metastatic PC involve mostly the skeleton.

To date, cancer-targeting therapy by trastuzumab is only indicated for metastatic breast cancer patients with an overexpression of HER-2/neu by IHC $(3+)$, while in PC this has not yet been evaluated.

In the present study, we evaluated the frequency of the expression of HER-2/neu in CTCs of patients with localised PC $v s$ patients with metastatic PC. HER-2/neu was detected in $54 \%$ of CTCs of patients with a metastatic disease and in $9.6 \%$ of CTCs of patients with localised PC $(P=0.004)$. This result suggests a potential value for HER-2/neu as a marker of tumour progression even when evaluated in CTCs. Indeed, the precise phenotypic profile of the CTCs truly responsible for clinical metastasis is not known to date. Table 4 summarises our results as compared to previously published manuscripts.

Among the 31 patients with localised PC, 16 patients were classified as 'low-risk patients' (serum PSA $\leqslant 10$ and Gleason score $\leqslant 6)$ and 15 patients were classified as intermediate or high-risk patients' (PSA: $10-20$ or Gleason score $=7$ and PSA $>20$ or Gleason score: $8-10)$. One of 16 patients and two of 15 patients are positive for the detection of HER-2/neu in these groups, retrospectively. To establish whether patients with localised disease and HER-2/neu-positive CTCs are at a higher risk of recurrence will 
require additional follow up. The status of HER-2/neu in the primary tumours of the patient population is unfortunately not available and will be very difficult to obtain since many patients were referred from outside centres.

In summary, the presence of HER-2/neu in CTCs of patients with $\mathrm{PC}$ is more frequent in patients with metastases than those with localised disease. This technique may be of great assistance to identify patients who may benefit from targeting HER-2/neu in the clinic. In the future, additional studies should evaluate a panel of different biomarkers in CTCs. This panel may include biomarkers (such as MMP2, MMP9 or E-cadherine) able to better predict the biological behaviour of CTCs (i.e. clinical metastasis). One limitation to this approach will be the amount of CTCs and therefore the corresponding RNA concentration available for such studies.

\section{ACKNOWLEDGEMENTS}

The work in the LS laboratory was supported by contract number FIGH-CT-1999-00002 from the CEC (Susgeninradcar).

\section{REFERENCES}

Agus DB, Scher HI, Higgins B, Fox WD, Heller G, Fazzari M, Cordon-Cardo C, Golde DW (1999) Response of prostate cancer to anti-HER-2/neu antibody in androgen-dependent and -independent human xenograft models. Cancer Res 59: $4761-4764$

Arai Y, Yoshiki T, Yoshida O (1997) c-erbB-2 oncoprotein: a potential biomarker of advanced prostate cancer. Prostate 30: 195-201

Corey E, Arfman EW, Oswin MM, Melchior SW, Tindall DJ, Young C Y-F, Ellis WJ, Vessella RL (1997) Detection of circulating prostatic cells by reverse transcriptase-polymerase chain reaction of human glandular kallikrein (hk2) and prostatic-specific antigen (PSA) messages. Urology 50: $184-188$

Craft N, Shostak Y, Carey M, Sawyers C (1999) A mechanism for hormonoindependent prostate cancer through modulation of androgen receptor signalling by the HER-2/neu tyrosine kinase. Nat Med 5(3): 280-285

De Marzo AM, Putzi MJ, Nelson WG (2001) New concepts in the pathology of prostatic epithelial carcinogenesis. Urology 57(Suppl 4A): $103-114$

Eccles SA (2001) The role of c-erbB-2/HER2/neu in breast cancer progression and metastasis. J Mammary Gland Biol Neopl 6(4): 393-406

Fossa A, Lilleby W, Fossa SD, Gaudernack G, Torlakovic G, Berner A (2002) Independent prognostic significance of HER-2 oncoprotein expression in pNO prostate cancer undergoing curative radiotherapy. Int J Cancer 99: $100-105$

Ghossein RA, Scher HI, Gerald WL, Kelly WK, Curley T, Amsterdam A, Zhang Z-F, Rosai J (1995) Detection of circulating tumour cells in patients with localised and metastatic prostatic carcinoma: clinical implications. J Clin Oncol 13: $1195-1200$

Gu K, Mes-Masson AM, Gauthier J, Saad F (1996) Overexpression of her-2/ neu in human prostate cancer and benign hyperplasia. Cancer Lett 99: $185-189$

Hara N, Kasahara T, Kawasaki T, Bilim V, Obara K, Takahashi K, Tomita Y (2002) Reverse transcription-polymerase chain reaction detection of prostate-specific antigen, prostate-specific membrane antigen, and prostate stem cell antigen in one millilitre of peripheral blood. Clin Cancer Res 8(6): $1794-1799$

Hynes NE (1993) Amplification and overexpression of the erbB-2 gene in human tumours: its involvement in tumour development, significance as a prognostic factor, and potential as a target for cancer therapy. Semin Cancer Biol 4: 19-26

Hynes NE, Stern DF (1994) The biology of erbB-2/neu/HER-2 and its role in cancer. Biochim Biophys Acta 1198: $165-184$

Israeli RS, Miller WH, Su SL, Powell CT, Fair WR, Samadi DS, Huryk RF, DeBlasio A, Edwards ET, Wise GJ, Heston WD (1994) Sensitive nested reverse transcription polymerase chain reaction detection of circulating prostatic tumor cells: comparison of prostatic-specific membrane antigen and prostate-specific antigen-based assays. Cancer Res 54: $6306-6310$

Katz AE, Olsson CA, Raffo AJ, Cama C, Perlman H, Seaman E, O’Toole KM, McMahon D, Benson MC, Buttyan R (1994) Molecular staging of prostate cancer with the use of an enhanced reverse-transcriptase-PCR assay. Urology 43: $765-775$

Lara PN, Meyers FJ, Gray CR, Gandour Edwards R, Gumerlock PH, Kauderer C, Tichauer G, Twardowski P, Doroshow J, Gandara DR (2002) HER-2/neu is overexpressed infrequently in patients with prostate carcinoma. Cancer 94(10): 2584-2589

Laribi A, Berteau P, Gala J, Eschwege P, Benoit G, Tombal B, Schmitt F, Loric S (2001) Blood-borne RT-PCR assay for prostasin-specific transcripts to identify circulating prostate cells in cancer patients. Eur Urol 39(1): $65-71$
Latza U, Niedobitek G, Schwarting R, Nekarda H, Stein H (1990) Ber-EP4: new monoclonal antibody which distinguishes epithelia from mesothelia. J Clin Pathol 43: 213-219

Mejean A, Vona G, Nalpas B, Damotte D, Brousse N, Chretien Y, Dufour B, Lacour B, Bréchot C, Paterlini-Bréchot P (2000) Detection of circulating prostate derived cells in patients with prostate adenocarcinoma is an independent risk factor for tumor recurrence. J Urol 163: 2022-2029

Menard S, Tagliabue E, Campiglio M, Pupa SM (2000) Role of HER2 gene overexpression in breast carcinoma. J Cell Physiol 182: 150-162

Morris MJ, Reuter VE, Kelly WK, Slovin SF, Kenneson K, Verbel D, Osman I, Scher HI (2002) HER-2 profiling and targeting in prostate carcinoma. A phase II trial of trastuzumab alone and with paclitaxel. Cancer 94(4): 980-986

O-charoenrat P, Rhys-Evans PH, Modjtahedi H, Eccles SA (2002) The role of c-erbB receptor and ligands in head and neck squamous cell carcinoma. Oral Oncology 38: 627-640

Osman I, Scher HI, Drobnjak M, Verbel D, Morris M, Agus D, Ross JS, Cordon-Cardo C (2001) HER-2/neu (p185neu) protein expression in the natural or treated history of prostate cancer. Clin Cancer Res 7: $2643-2647$

Pergram MD, Finn RS, Arzoo K, Beryt M, Pietras RJ, Slamon DJ (1997) The effect of HER-2/neu overexpression on chemotherapeutic drug sensitivity in human breast and ovarian cancer calls. Oncogene 15: $537-547$

Ross JS, Sheehan CE, Hayner-Buchan AM, Ambros RA, Kallakury BVS, Kaufman RP, Fisher HAG, Rifkin MD, Muraca PJ (1997) Prognostic significance of HER-2/neu gene amplification status by fluorescence in situ hybridization of prostate carcinoma. Cancer 79(11): 2162-2170

Sadasivan R, Morgan R, Jennings S, Austenfeld M, Van Veldhuizen P, Stephens R, Noble M (1993) Overexpression of HER-2/neu may be an indicator of poor prognosis in prostate cancer. J Urol 150: 126-131

Schechter AL, Hung MC, Vaidyanathan L, Weinberg RA, Yang-Feng TL, Francke U, Ullrich A, Coussens L (1985) The neu gene: an erbBhomologous gene distinct from and unlinked to the gene encoding the EGF receptor. Science 229: $976-978$

Scher HI, Heller G (2000) Clinical states in prostate cancer: toward a dynamic model of disease progression. Urology 55: 323-327

Seiden MV, Kantoff PW, Krithivas K, Propert K, Bryant M, Haltom E, Gaynes L, Kaplan I, Bubley G, DeWolf W, Sklar J (1995) Detection of circulating tumor cells in men with localized prostate cancer. J Clin Oncol 12: $2634-2639$

Signoretti S, Montironi R, Manola J, Altimari A, Tam C, Bubley G, Balk S, Thomas G, Kaplan I, Hlatky L, Hahnfeldt P, Kantoff P, Loda M (2000) Her-2-neu expression and progression toward androgen independence in human prostate cancer. J Natl Cancer Inst 92(23): 1918-1925

Slamon D, Leyland-Jones B, Shak S, Fuchs H, Paton V, Bajamonde A, Fleming T, Eiermann W, Wolter J, Pegram M, Baselga J, Norton L (2001) Use of chemotherapy plus a monoclonal antibody against HER2 for metastatic breast cancer that overexpressed HER2. $N$ Engl J Med 344: $783-792$

Slamon DJ, Clark GM, Wong SG, Levin WJ, Ullrich A, McGuire WL (1987) Human breast cancer: correlation of relapse and survival with amplification of the Her-2/neu oncogene. Science 235: 177-182

Small EJ, Bok R, Reese DM, Sudilovsky D, Frohlich M (2001) Docetaxel, estramustine, plus trastuzumab in patients with metastatic androgenindependent prostate cancer. Sem Oncol 4(15): 71-76

Sokoloff MH, Tso CL, Kaboo R, Nelson S, Ko J, Dorey F, Figlin RA, Pang S, DeKernion J, Belldegrun A (1996) Quantitative polymerase chain reaction does not improve preoperative prostate cancer staging: 
Detection of circulating tumour cells in prostate cancer patients $\mathrm{N}$ Ady et al

a clinicopathological molecular analysis of 121 patients. J Urol 156: $1560-1566$

Soria JC, Gauthier LR, Raymond E, Granotier C, Morat L, Armand J-P, Boussin FD, Sabatier L (1999) Molecular detection of telomerase-positive circulating epithelial cells in metastatic breast cancer patients. Clin Cancer Res 5: 971 - 975

Wood DP, Banerjee M (1997) Presence of circulating prostate cells in the bone marrow of patients undergoing radical prostatectomy is predictive of disease free survival. J Clin Oncol 15: 3451-3457
Yamamoto T, Ikawa S, Akiyama T, Semba K, Nomura N, Miyajima N, Saito T, Toyoshima K (1986) Similarity of protein encoded by the human cerb-B-2 gene to epidermal growth factor receptor. Nature 319: 230 - 234

Yamauchi H, Stearns V, Hayes DF (2001) When is a tumor marker ready for prime time? A case study of c-erbB-2 as a predictive factor in breast cancer. J Clin Oncol 19: 2334-2356

Zhau HYE, Zhou J, Fraser Symmans WF, Chen B-Q, Chang S-M, Sikes RA, Chung LWK (1999) Transfected neu oncogene induces human prostate cancer metastasis. Prostate 28: $73-83$ 